by Zheng Jiandong

\title{
Significance of the Altun Tagh fault of China
}

The Altun Tagh fault, a major left-lateral strike-slip faut in Asia, has been of interest to many scientists. On the basis of field investigations, the Altun Tagh fault is known to be very active as it not only exhibits strike-slip and compressional features but also has produced many historical seismic events. It bounds the Tibetan Plateau, separates the Tarim and Qiadam Basins, and plays an important role in the geodynamic evolution of that region.

\section{Introduction}

The Altun Tagh fault, a major left-lateral strike-slip faul in Asia extends about $1.600 \mathrm{~km}$ from westem I.azhulong eastward to the Jinta Basin, where it becomes concealed in the Badian Jaran desert Although earth scientists know few details about the fault's geologi sertings because of its location at high altitudes and in sparsely populated to nonpopulated areas, many scientists are aware of it existence and significance. Zhang Wenyou suggested (Tectonic Mal? Compiling Group, 1974) that the Altun Tagh is a transfotm faul hetween the western Kunlun Shan (Mouncains) and the Qilian Shat (fig. 1). Molnar and Tapponnier (1975) alssumed from their interpretations of Landsat imagery that the total displacement on the Alua

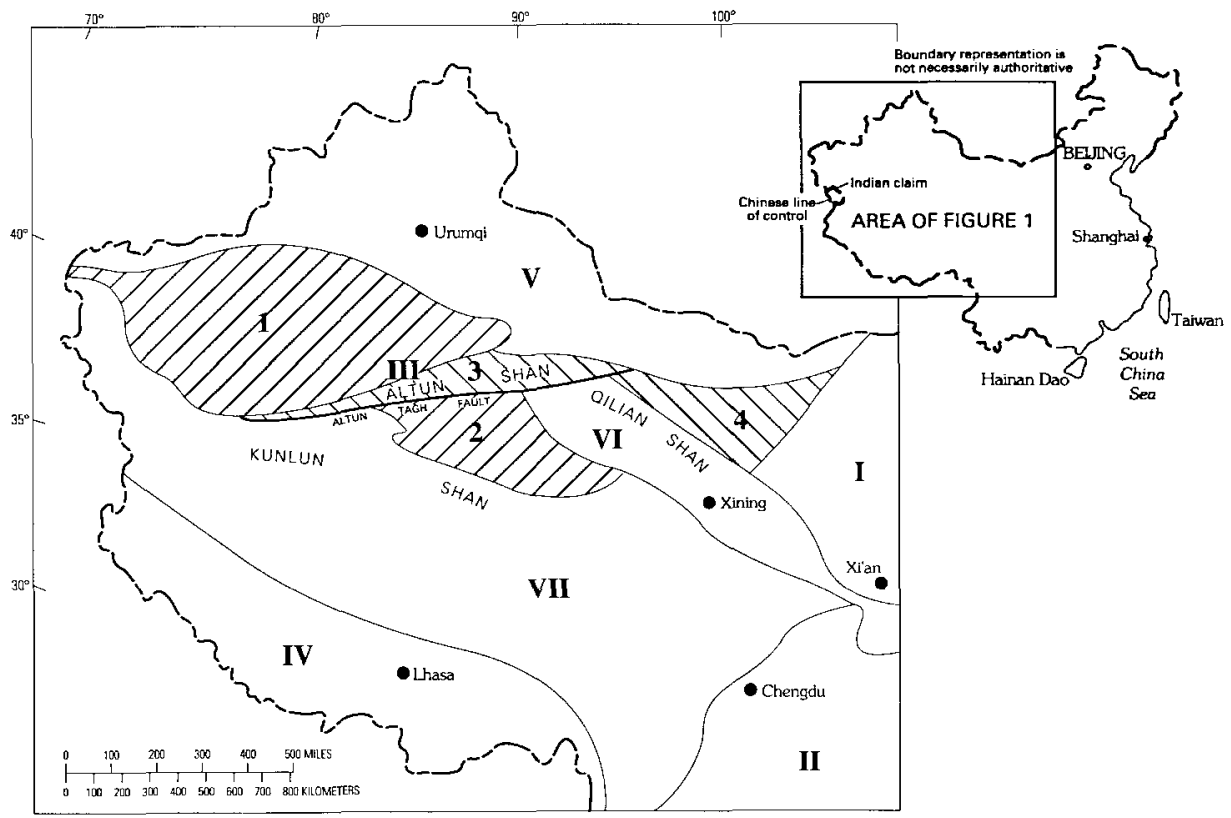

Figure I.-Geotectonic provinces of western China: I, North China platform; $I I$, Yangtze platform; $I I I$, Northwest platform; $I V$, Middle-South Tibet continental block; V, Tienshan-MongoliaXing-ganling fold system; VI, Qinling-Qilian fold system; and VII, Kunlun-Shanjiang fold system (Shanjiang: Jinshajiang,
Lancangjiang, and Nujiang). The Altun Tagh fawlt is located in the Northwest platform (III, shown by ruled patterns), which contains: 1, Tarim depression; 2, Qiadam depression: 3, Alun fault uplift: and 4, Alxa platform uplift. 


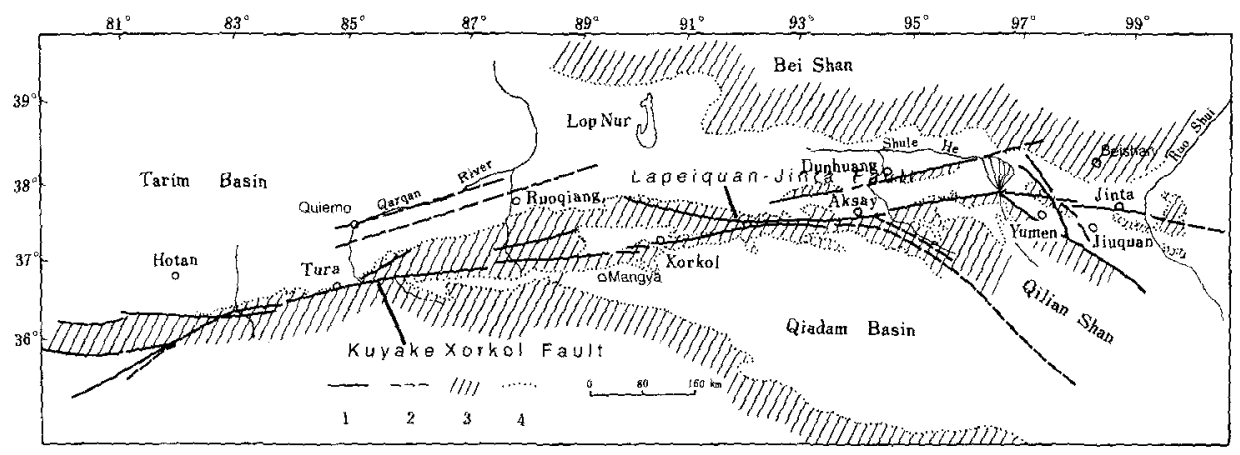

Figure 2.-Distribution of the Altun Tagh fault belt, Explanation: 1, fault; 2, buried or uncertain fault; 3, uplifted region; 4, basin.

Tagh fault was about $400 \mathrm{~km}$. Zhao Zhivun and Zhu Shida (1980) supported the idea that the Kuyake fault. part of the western Altur Tagh fault. is a rift valley that separates the Kurlun Shan into its western and eastern parts. Ren Jishun and others (1980) pointed out that the Altur Tagh fault, one of the rloost importart sheat fauls in western China, extends irom the Alum Shan east to Beisharn. Ding Guoyu (1982), in comparing the active fauts of China, pointed out that the Alur Tagh fault is the most active and that the slip rate is about $6 \mathrm{~mm} / \mathrm{yr}$ based on the oftset of stream chamels. A regional geological survey was conducted in the 1980s by the Geological Bureau of the Xinjiang Cygur Autonomous Rcgion, and geological repurts on the Xorkol and Baxkorgan steets (scale 1:200,000) were puhlished in 1982. Molnar and Deng Qidong (1984) determined the approxinate averatge rates of defomiation in central and eastera Asia on the batsis of large carthquake events. They citimated that leftlateral shear has been more than $10 \mathrm{~mm} / \mathrm{yr}$ on easterly trending planes in nothwestern Tibet and Gansa. Furthermore, they pointed out that slip on the Altun Tagh fault is poorly represented. The State Seissnological Bureau of China organized a progratn to begin research on the active Altun Tagt fault in 1985. The author took part in the field investigations in the Tam Basin, Qiadam Basin, and Alum Shan from 1985 to 1988 , and some of the preliminary conclusions are included in this paper.

\section{Basic characteristics of the Altun Tagh fault}

Tectonically, the ditun region is refersed to at a part of the Northwest platform. which consists of four geologio unis: the Tarim depressiom, the Qindam depression, the Altur fault uplift, and the Alxa plation uplifi (fig, 11 (Yang Weiran and shers, 1984).

(On the basis of field investigntions, the stuctural spyes in the Alun Tagh fult boll wre very complex hut, in general. comsist of a series of teft-luteral strike-slip faults. The total length of the fault belt is at least $1.600 \mathrm{~km}$ some geologists assume that it exlends in mortheastem China and is. therefore. about $3,500 \mathrm{~km}$ long. The trend of the fault belt is about $\wedge .79^{\circ} \mathrm{E}$. and two main branches maty be distinguished: the southem, named the Kuyake-Xotkol fiult, and the

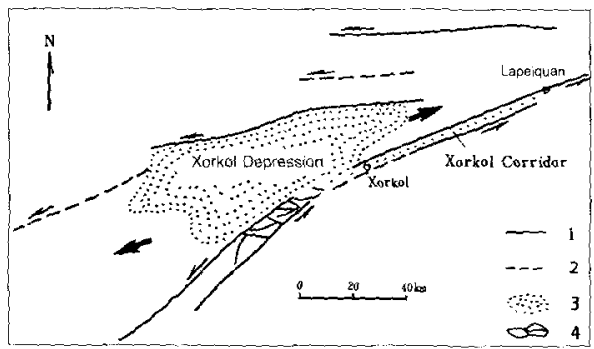

Figare 3. - The Xarkal pull-apart basin (interpreted from Landsat image ). Explanation: 1, fault; 2, fault interpreted from Landsat image; 3 , depositional basin; 4, compressional structure.

northern, named the Lapeiquan-Jinta favk (fig. 2). The dip of the taults is about $70^{\circ}$. Dips in the western and eastern patts of the foult bett are inclined toutheast, whereas thase in the central part are inclined northwest. The Altun Tagh fault has the fealures of a strike-sip fault. such as the Xorkol pull-apurt basit (fig. 3) where ite thickness of the Cenozos rocks is about $4.5(9) \mathrm{m}$, as wall as the thrust of overtirust features of a compressionial fault. Figures 4 and 5 show examples of thrusting along the fauth belt.

At the matgins of the Turim and Qiadam depressions are ex posed Precimbrian rocks, and the Altun Shan consist essentially of the Precambrian Dunhuang and Danghe Groups. Paleneroic rocks are located at the southen margins, and Mesozuc to Cenorgic terestrat sodiments are expowed mainly in the foredeeps and internontane banisis sfigs. 2 and 61. Thus, I suggest that the Altun shan ate not part of a Catedonian or Variscan fold belt but, rather, arc in a stable block. The active history of the Alsun Tagh fauls could be dated to the Varistan orngeny becalle many Variscan granites are intruded along it. I suggest, however. that the fiull wir incalized by intensive action is the Cenoroic Era following the tensional tectonic anviron- 
ment in the Mesozoic Era, when many Jurassic and Cretaceous faulted depressive basins, including the $\mathrm{Xorkol}$ and Jinta Basins, were distributed along about $1,000 \mathrm{~km}$ of the fault and provided weaker lithosphere. These Jurassic and Cretaceous basins are easy to identify in the field: the Early and Middle Jurassic basins have coal-bearing formations and are called black basins, whereas the Late Jurassic and Cretaceous basins contain red rocks and are called red basins. Upper Triassic formations are exposed along the road from Mangya city to the region of Ruogiang (fig. 2). According to the No. 6 Geological Team of Qinghai Province, this is the first discovery of Upper Triassic formations between the Tarim and Qiadam Basins and is important in the explanation of their evolution. The principal strike-slip movement of the Altun Tagh Eault took place in the early Cenozojc Era contemporaneously with the collision between the Indian continent and Eurasian plate. After the collision, the total displacement on the Altun Tagh fault was $250 \mathrm{~km}$ according to the offset of Jurassic coal in the Qiemo and Gase mines (fig. 7) (Zheng Jiandong, 1989).
The Altun Tagh is an active fault and has cut the Neogene and Pleistocene strata at many places. The Wuzunxiao dry salt lake is displaced about $400 \mathrm{~m}$; gullies, rivers, and ridges are sinistrally offset by the fault; and a series of scarps has formed at the surface. The maximum offset on a stream channel is about $55 \mathrm{~km}$ in the Qurqart River in Xinjiang Uygur Autonomous Region (fig. 6). The average slip rate on the Altun Tagh fault has been about $7 \mathrm{~mm} / \mathrm{yr}$ during the Cenozoic, an estimate obtained by the use of the velocitics of retrogressive erosion, vertical crosion, and horizontal offsets. The Holocene slip rate varies in different parts of the fault belt and ranges from 4.5 to $10.3 \mathrm{~mm} / \mathrm{yr}$ according to data from field investigations. The Altun Tagh fault belt is a seismically active zone that has produced 23 earthquakes of magnitude $(M) \geq 5$ (table 1 ). The earthquakes of 3 and 12 July $1924(\mathrm{M}=7 \mathrm{1} / 4)$, which occurred in eastern Minfeng region, were the largest recorded in the seismic zone (fig. 8). Recently, a few ancient seismic deformation belts have been found along the zone.

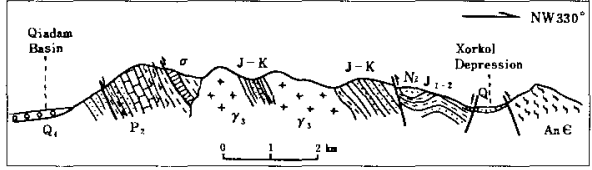

Figure 4,-Geologic section near Xorkol. The Alun Tagh fault actually consists of a series of faults. The main fault is located at the north end of the section where Precambrian rocks are thrust over younger rocks. Explanation: $\gamma 3$, Variscan granite; $\sigma$, basic or ultrabasic rock; An€, Precambrian; Pz, Paleozoic; J, Jurassic; K, Cretaceous; $N$, Neogene; $Q$, Quaternary.

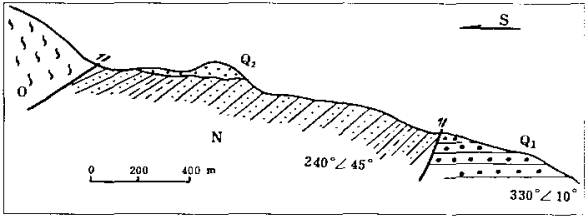

Figure 5. - Geologic section east of Aksay (see fig. 2). The Altun Tagh fault consists of two planes. On the southern plane, Ordovician $(O)$ limestone and shells are thrust over Neogene $(N)$ sand. stone; on the northern, the sandstone is, in turn, thrust over Quaternary $(Q)$ conglomerate laterally.

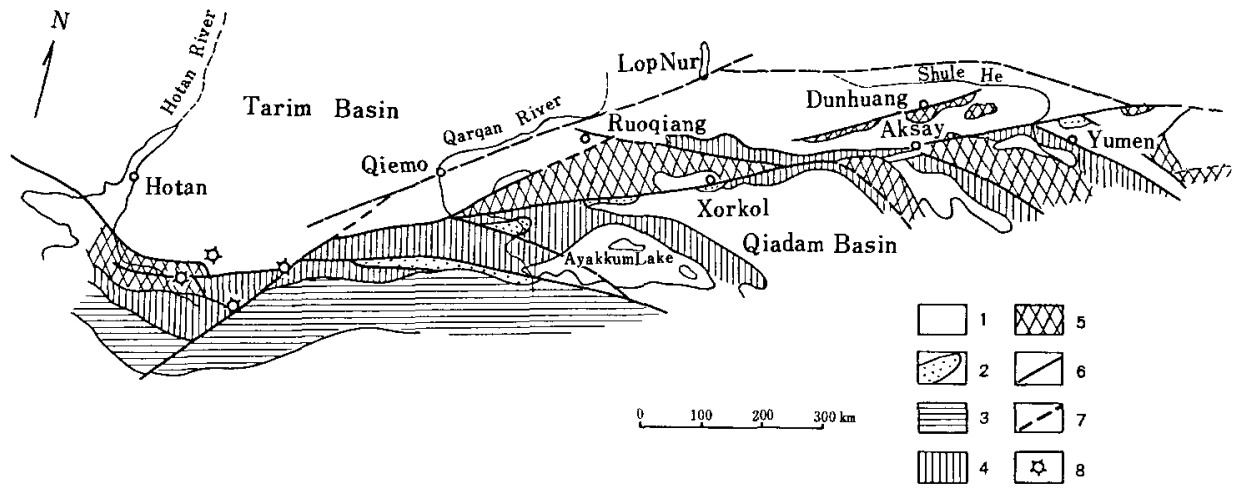

Figure 6. - Simplified geologic map of the Altun Tagh fault belt. Explanation: 1 , Cenozoic basin; 2 , Jurassic-Cretaceous terrestrial basin; 3 , Triassic formations; 4 , Paleozoic rocks; 5 , Precambrian rocks; 6, fault; 7 , uncertain fault; 8 , Quaternary volcano. 


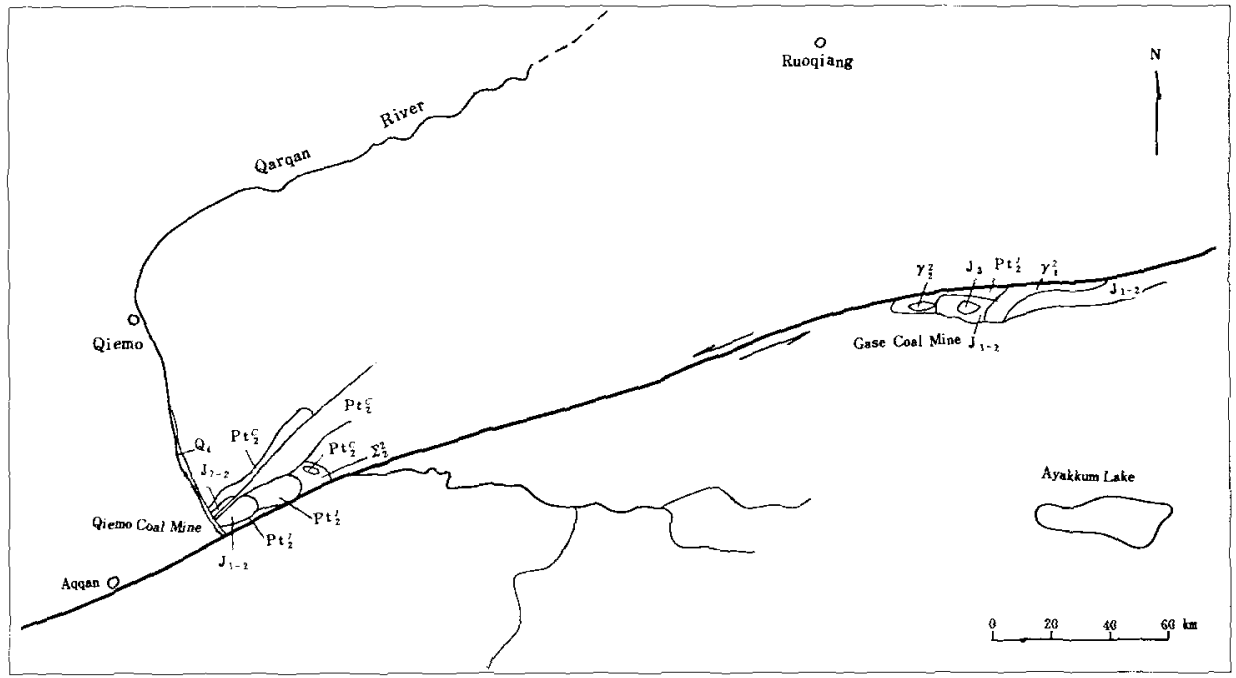

Figure 7. - Geologic evidence for maximum displacement of about $250 \mathrm{~km}$ on the Alun Tagh fault at mines in Jurassic coal. Note that Qarqan River has been offset about $55 \mathrm{~km}$ (Zheng Jiandong, 1989).

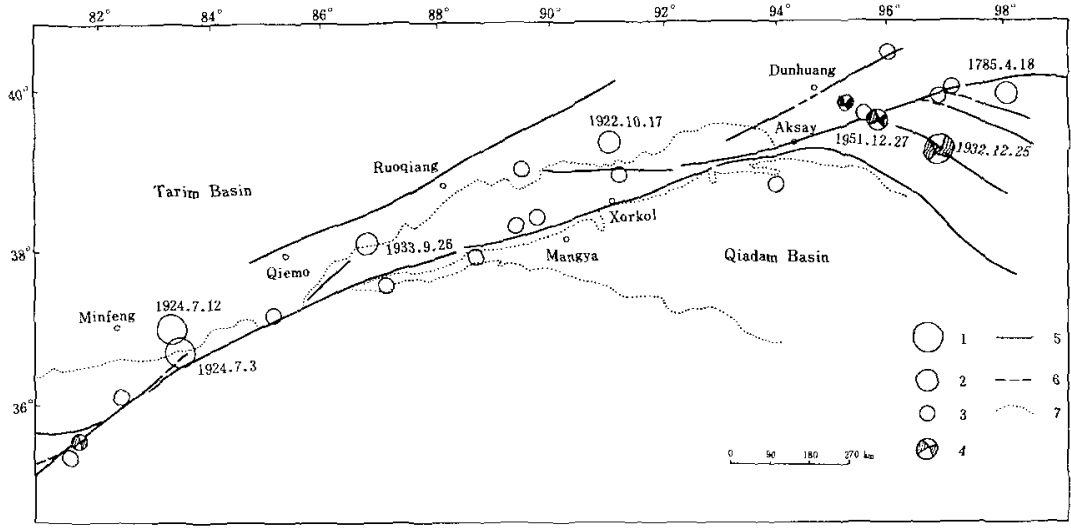

Figure 8. - Distribution of epicenters of earthquakes along the Altun Tagh fault belt. Explanation: $1, M=7 ; 2, M=6.9-6$; 3. $M-5.9-5 ; 4$, focal mechanism, shaded areas showing the tensional region: eastern from Qin Baoyan (1988) and western from the Seismological Bureau of the Xinjiang Uygur Automomoux Region (1985); 5, fault; 6, uncertain fault; 7 , basin. Dates are shown for the larger earthquakes. 
Table 1. - Earthquakes of $M=5$ along the Altun Tagh fault belt

[Abbreviation: [r., [Ditto]

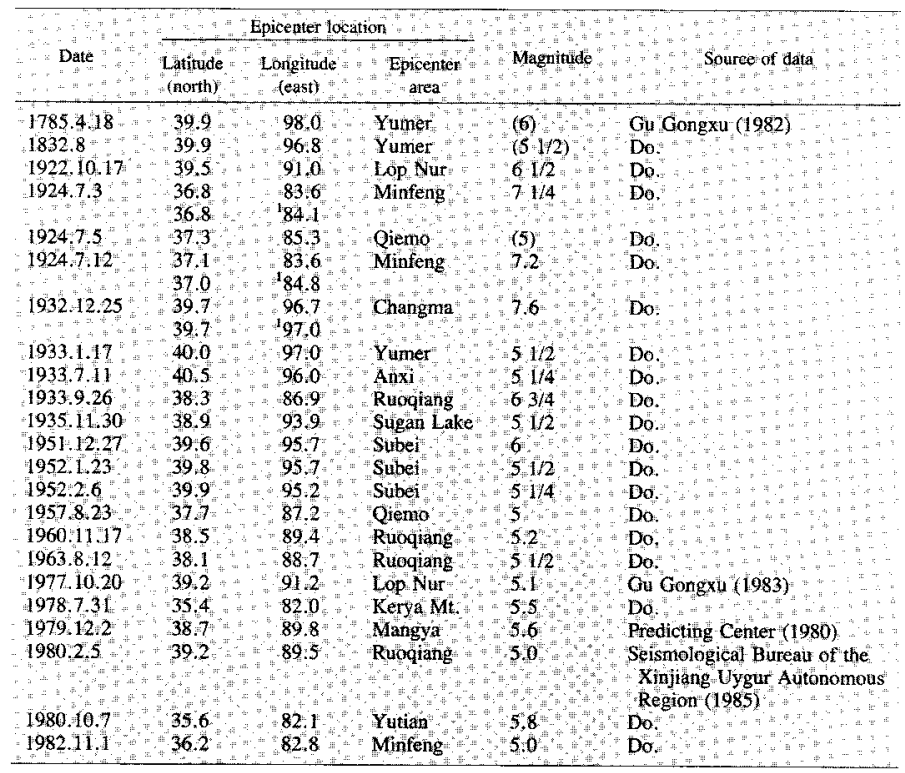

Mikroscopic earthujuake upicente:

\section{Geodynamic history}

The Altur Tagh fault is the active northwestern boundary of the Tibetan Plateau in the Asian continent. and the fault plays an important role in the geodynamic history of the plateau. The boundary is a sharp gravity gradient zone and a crustal differential zone, and it controls the distribution of continental basins such as the Qiadam. Xorkol, and Jiuquan (fig. 2). However, the Altun Tagh fault might be interpreted as a transform fault becaluse it is very long and terminates in other features, for instance, the Qilian compressional belt to the east and the Kunlun shear-tensional belt to the west ifig. 1). As the Indian continent collided with Eurasia, the Altun Tagh fault intersected the maximum principal stress at a large angle and thereby produced the mechanism in transpression.

The Altun Tagh fault and the Karakoram fault form a conjugate shear couple (fig. 9). The first faull is sinistral and the second is dextral, which creatcs a tectonic escape for the Qiangton block, the northern part of the Tibetan Plateau. The rate of castward tectonic escape of the Qiangton block is about $5-10 \mathrm{~mm} / \mathrm{yr}$ (Zheng Jiandong. 1988). Consequently, the rate of northward movement of western Asia hat decreased because part of the energy is consumed in the continental crustal shortening and thickening and part is distributed in transcurrent movement. For instunce. the Tibetan and Persian Plateaus are symmetrical to the Pamir Plateau collision comer. and their escape rates are about $5-10 \mathrm{~mm} / \mathrm{yr}$ castward and westuard. respectively.

The tremendous uplift of the Tibetan Platetu is the consequence of continental crustal shorterting, thickening, and folding. A series of thrust slabs and Precambrian blocks on the southern and northem margins of the plateat are another effect of the unified uplift procesis. Neotectonic characteristics on the northern and southern sides of the Altun Shan are quite different: on the north. the mountuins seem to drop straight into the Tarim Basin. and on the south. the Altun Shan are being uplifted along with the Tibetan Plateau.

\section{Acknowledgments}

This work has supported by the State Seismological Bureau of China. In addition. I would like to express my thanks to the Seismological Bureaus of the Xinjiang Lygur Autonomous Region and of Qinghai Province for their kind help in the field investigations. 


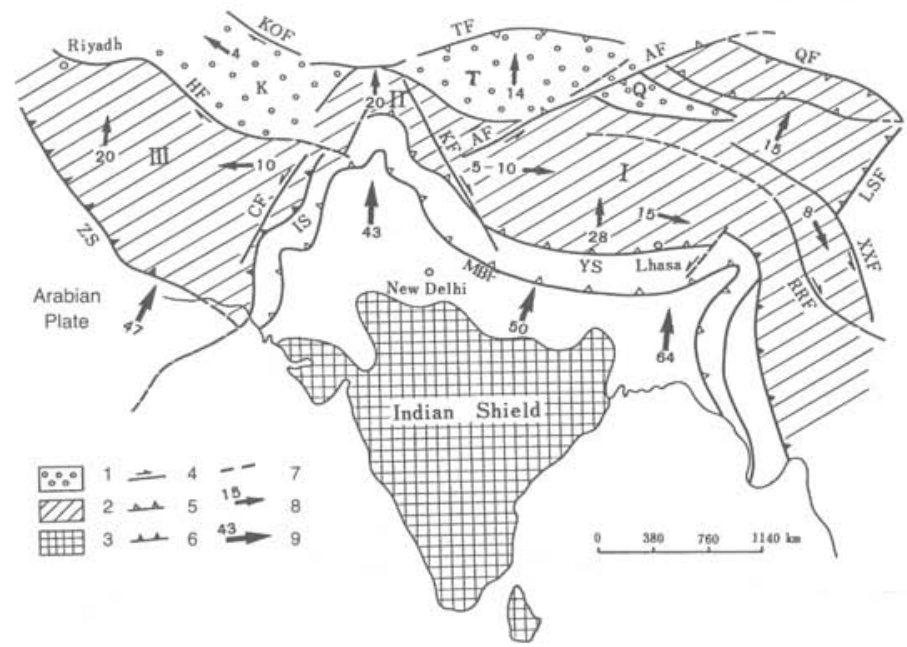

Figure 9.-Schematic geodynamic map of the western part of the Asian continent. Explanation: 1, Cenozoic continental basin; 2, young plateau; 3, Precambrian shield; 4, strike-slip fault; 5 , thrust fault; 6 , collision zone; 7 , uncertain fault; 8 , rate and direction of movement of the continental block $(\mathrm{mm} / \mathrm{yr}) ; 9$, relative rate and direction of movement of the plate $(\mathrm{mm} / \mathrm{yr})$. Also, I, Tibetan Plateau; II, Pamir Plateau; III, Persian Plateau; K, Karkum Basin; Q, Qiadam Basin; T, Tarim Basin; AF, Altun Tagh fault; CF, Chaman fault; HF, Herat fault; IS, Indus suture; KF, Karakoram fault; KOF, Kopet fault; LSF, Longmen-Shan fault; MBF, main boundary fault; $Q F$, Qilian fault; RRF, Red River fault; TF, Tien Shan fault; XXF, Xianshuhe-Xiaojiang fault; YS, Yarlung Zambo suture; ZS, Sagros suture.

\section{References}

Ding Guoyu, 1982, Quatemary faulting in China, in Liu Tung-sheng, ed., Quatemary geology and environment of China: Beijing. China Ocean Press, p. 170-175.

Geological Bureau of the Xinjiang Uygur Autonomous Region, 1982. The Xorkol and Baxkorgan sheets of geological reports: Beijing. Geological Publishing House, scale 1:200,000. [In Chinese. ]

Gu Gongxu, chicf compiler, 1982. The catalogue of earthquakes in China (1831 B.C.-1969 A.D.): Beijing. China Academic Publisher. IIn Chinese.

-1983. The catalogue of earthquakes in China (1970-1979): Beijing. Seismology Press. [ln Chinese.]

Molnar, P.. and Deng Qidong. 1984, Faulting associated with large earthquakes and the average rate of deformation in central and easterm A sia: Journal of Geophysical Research, v. 89, no. B7, p. 6203-6227.

Molnar, P., and Tapponnier. P., 1975, Cenozoic tectonics of Asia: Effects of a continental collision: Science, $v$, 189, no, 4201, p. $419-426$.

Predicting Center. State Seismological Bureau of China, 1980, Seismic information in 1979: Dizhen Zhanxian, no. 1, p. 2-3. [In Chinese.]

Ren Jishun, Jiang Chunfa, Zhang Zhengkun, and Qin Deyu, 1980, The geotectonic evolution of China: Beijing. China Academic Publisher. 124 p. (In Chinese.)

Seismological Bureau of the Xinjiang Uygur Autonomous Region. 1985. The corpus of the earthquake information: Beijing. Seismology Press. [In Chinese.]

Tectonic Map Compiling Group. Institute of Geology. Academia Sinica, 1974. A preliminary note on the basic tectonic features and their developments in China: Scientia Geologica Sinica, no 1, p. 1-17,

Yane Weiran, Guo Tieying, Lu Yuanliang. Zheng Jiandong. Su Jian, and
Ma Xingyuan, 1984, "Opening" and "closing" in the tectonic evolution of China: Earth Science, Journal of Wuhan College of Geology, no. 3. p. $39-56$.

Zhao Zhiyun and Zhu Shida, 1980. The Kuyake rift valley obliquely cut the Kunlun Mountain: Kexue Tongbao, no, 24, p. 1131-1133. [In Chinese.]

Zheng Jiandong, 1988, A preliminary study of geodynamics of the QinghaiXizang (Tibet) plateau: Geoscience Journal of Beijing Graduate School. Wuhan College of Geology, no. 2, p. 194-206. 1989. Dynamics of the Altun Tagh fault (in press).

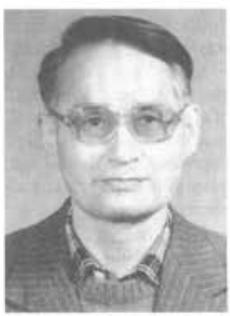

Zheng Jiandong is a Professor and Senior Geologist at the Institute of Geology, State Seismological Bureau (100011, Beijing. China), as well as a member of Regional Geology and Metallization of the Geological Society of China. Engaged in fieldwork from 1957 to 1979 , he studied struc. tural geology, geophysics, and geodesy. Since then, he has worked on the seismotectonics and geodynamics of western China, particularly in the Tibetan Plateau and in the Tarim and Oiadam Basins. He is interested in applying plate tectonics to the study of the Asian continent. 